\title{
PENGUATAN DALAM PEMBELAJARAN BAHASA JEPANG OLEH GURU BAHASA JEPANG SMA NEGERI 1 SUKASADA
}

\author{
I M. A. S. Aryawan'1, D. M. S. Mardani' ${ }^{2}$, I W. Sadyana ${ }^{3}$ \\ Jurusan Pendidikan bahasa Jepang, \\ Universitas Pendidikan Ganesha \\ Singaraja, Indonesia \\ e-mail: atsa.agus@gmail.com \\ desak.mardani@undiksha.ac.id wayan.sadyana@undiksha.ac.id
}

\begin{abstract}
Abstrak
Penelitian ini bertujuan untuk mengetahui (1) Model-model penguatan yang digunakan oleh guru bahasa Jepang dalam pembelajaran bahasa Jepang di SMA Negeri 1 Sukasada, (2) Penggunaan bahasa Jepang dan kejepangan dalam penguatan oleh guru bahasa Jepang dalam pembelajaran bahasa Jepang di SMA Negeri 1 Sukasada. Subjek dalam penelitian ini adalah guru bahasa Jepang di SMA Negeri 1 Sukasada. Pengumpulan data dilakukan dengan metode observasi, dokumentasi, dan wawancara, kemudian dianalisis menggunakan metode deskriptif kualitatif. Hasil penelitian ini adalah (1) Guru bahasa Jepang dalam pembelajaran bahasa Jepang di SMA Negeri 1 Sukasada menggunakan penguatan verbal berupa kata dan kalimat dalam bentuk pujian, persetujuan, dukungan, penghargaan, teguran dan nasihat, penguatan nonverbal berupa mimik dan gerak badan (gestural), dengan cara mendekati, dengan sentuhan, dan dengan kegiatan yang menyenangkan. Penguatan berupa simbol atau benda tidak dilakukan guru. (2) Penggunaan bahasa Jepang dan kejepangan dalam penguatan dilakukan guru dengan cara menggunakan pujian, dukungan, pengakuan, dan penghargaan dalam bahasa Jepang, pengamalan budaya Jepang, serta menceritakan perbandingan budaya, pola pikir, dan prinsip orang Jepang.
\end{abstract}

Kata kunci: Bahasa Jepang, Model, Pembelajaran, Penguatan

\section{要旨}

本論の目的は、（1）公立スカサダ第一高等学校の日本語学習時における日本語指導者の指 導モデル、（2）当校日本語指導者の日本語学習時の日本語および日本文化紹介などの利用状況を明 らかにしたものである。対象は公立スカサダ第一高等学校の日本語指導者である。データは授業観察 ドキュメント、インタビューにより収集し、それを定性的記述法により分析した。結果、（1）当 校の日本語学習時における日本語指導者は、単語、文章による言語的指導では、称賛、認識または承 認、サポートと感謝、警告とアドバイスなどを施し、動作表情による非言語的指導では、ジェスチャ 一、近接、ユニークな動きの表情を使用する。シンボルまたは物を使用する指導がない。（2）当校 指導者の日本語の使用状況は、ほめる、サポート、認識、感謝を表現する場合に使用され、日本文化 の紹介においては、比較文化、日本人の基本的考え方、しきたりなどを指導している。

キーワード：日本語、モデル、学習、指導力

\section{Pendahuluan}

Guru merupakan salah satu faktor yang menentukan peningkatan kualitas pendidikan. Kualitas pendidikan akan semakin meningkat apabila siswa memiliki kesadaran belajar. Kesadaran belajar memiliki timbal balik dengan motivasi belajar. Penumbuhan motivasi belajar bagi siswa merupakan permasalahan yang sering timbul dalam pendidikan. Sering kali siswa belajar tidak berdasarkan atas kesadarannya sendiri bahwa belajar merupakan hal yang sangat penting. Begitu pula dalam pembelajaran bahasa Jepang di Sekolah Menengah Akhir (SMA). Dalam hal ini, peran guru sangat penting untuk meningkatkan motivasi belajar siswa dan mendorong siswa unuk berperilaku positif.

Akhir-akhir ini sering terjadi kasus guru yang mengupayakan untuk menghilangkan perilaku negatif atau menyimpang siswanya dan agar lebih termotivasi untuk belajar, namun dengan cara yang kurang tepat sehingga sampai jatuh keranah hukum. Perlu kesabaran dan 
keprofesionalan sebagai seorang guru agar mampu mengarahkan siswa ke arah yang lebih positif, bukan malah membuat siswa tunduk pada ketakutan, sehingga bukannya siswa termotivasi dan tumbuh kesadaran dari dalam dirinya untuk belajar, tetapi malah semakin terpuruk.

Sebagai guru yang profesional, guru harus menguasai berbagai keterampilan dasar dalam mengajar, menurut Direktorat Tenaga Kependidikan (dalam Barnawi dan M. Arifin, 2012:201) terdapat delapan keterampilan dasar mengajar, yaitu keterampilan bertanya, keterampilan memberi penguatan, keterampilan mengadakan variasi, keterampilan menjelaskan, keterampilan membuka dan menutup pelajaran, keterampilan membimbing diskusi kelompok kecil, keterampilan mengelola kelas, serta keterampilan mengajar kelompok kecil dan perorangan.

Keterampilan memberikan penguatan merupakan salah satu keterampilan yang diperlukan untuk meningkatkan motivasi belajar siswa dan menghapuskan perilaku menyimpang siswa, sehingga dapat meningkatkan kualitas pembelajaran. Dalam memberikan penguatan dibutuhkan keahlian seorang guru dalam berinteraksi dengan siswa. Semakin terampil seorang guru dalam memberikan penguatan, maka dapat dilihat semakin baik kemampuannya dalam berinteraksi dengan siswa. Sehingga pemberian penguatan juga dapat menumbuhkan keakraban antara guru dengan siswa. Dengan penguatan, siswa dapat mengetahui apakah perilakunya benar atau salah, sehingga ketika telah diketahui bahwa perilakunya benar, maka siswa diharapkan dapat mempertahankan dan meningkatkan perilaku positifnya. Sebaliknya ketika perilaku siswa yang negatif atau menyimpang direspons dengan penguatan berupa teguran atau hukuman, diharapkan dapat menghilangkan perilaku negatif dari siswa.

Berbicara mengenai penguatan yang dilakukan untuk merespons perilaku siswa yang menyimpang atau negatif perlu dilakukan dengan hati-hati. Jangan sampai penguatan yang diberikan bersifat kasar, mencemooh, menghina atau yang bersifat kekerasan fisik. Penguatan berupa hukuman menurut Djamarah dan Aswan Zein (2006:156) hendaknya diberikan berupa hukuman yang bersifat mendidik. Dengan demikian, hal-hal yang tidak diinginkan diharapkan tidak terjadi.

Jika ditinjau dari pembelajaran bahasa Jepang, penguatan juga dapat menambah pengetahuan siswa mengenai kosakata, pola kalimat, dan budaya dalam bahasa Jepang, sehingga dapat digunakan juga sebagai pelatihan dalam memahami budaya dan bahasa Jepang lebih dalam lagi. Dapat kita ambil contoh seperti penggunaan penguatan "ii desu ne", "hai, sugoi desu" dan lain sebagainya dapat menambah penguasaan kosakata bahasa Jepang. Pembiasaan-pembiasaan dengan memberikan penguatan semacam ini dapat menjadi langkah yang baik untuk melatih dan membiasakan siswa dalam penggunaan bahasa Jepang.

Berdasarkan penjelasan yang telah dipaparkan sebelumnya maka perlu bagi seorang guru untuk mengembangkan keterampilannya dalam memberikan penguatan, mengingat keterampilan ini dapat meningkatkan motivasi belajar siswa dan membutuhkan keahlian dari guru dalam memberikan penguatan ketika berinteraksi dengan siswa dalam kegiatan belajar mengajar. Terutama ketika siswa berperilaku menyimpang yang akan menjadi tantangan untuk guru agar dapat memberikan penguatan yang tidak bersifat menyakiti perasaan maupun fisik siswa, melainkan diharapkan guru dapat memberikan penguatan yang berdampak positif bagi siswa.

Pentingnya pengembangan dan penerapan penguatan dalam pembelajaran sebagai bentuk upaya guru untuk menumbuhkan, menjaga, dan meningkatkan motivasi siswa dalam belajar telah diupayakan implementasinya salah satunya oleh guru bahasa Jepang di SMA Negeri 1 Sukasada. Hal tersebut dapat terlihat berdasarkan pengalaman PPL-Real yang pernah dilakukan di SMA Negeri 1 Sukasada, guru SMA Negeri 1 Sukasada yang mengampu mata pelajaran bahasa Jepang menerapkan keterampilan penguatan dalam kegiatan pembelajaran. Salah satu contoh yang dapat dilihat adalah ketika terdapat seorang siswa yang telah kembali bersekolah setelah beberapa lama tidak bersekolah karena memiliki motivasi belajar yang rendah yang kemudian diberikan penguatan oleh guru pengampu mata pelajaran bahasa Jepang dengan mengajak seluruh siswa untuk bertepuk 
tangan sebagai penghargaan atas kembalinya semangat siswa tersebut untuk bersekolah kembali. Dari hal tersebut dapat dianalisis bahwa dalam memberikan penguatan, guru melihat dari sudut pandang positif terhadap siswa yang telah kembali bersemangat bersekolah, bukannya memandangnya dari sudut pandang negatif karena baru kembali bersekolah. Hal tersebut terjadi karena guru telah memikirkan mengenai bentuk penguatan seperti apa yang sesui diberikan kepada siswa dengan mempertimbangkan karakter dari siswa bersangkutan dan memikirkan dampak yang akan ditimbulkan ketika diberikan penguatan.

Selain itu, telah dilakukan pula observasi kembali. Berdasarkan observasi yang telah dilakukan, dapat dilihat bahwa guru pengampu mata pelajaran bahasa Jepang di SMA Negeri 1 Sukasada menggunakan berbagai variasi penguatan baik penguatan verbal maupun penguatan nonverbal dalam merespons perilaku positif maupun perilaku negatif siswa. Penguatan yang diberikan guru seperti penguatan verbal dalam bentuk pujian (ya, bagus sekali, sugoi desu, ii desu) mendekati siswa yang membahas hal diluar konteks pelajaran, dan memberi atau menunjukkan bahasa isyarat stop untuk menghentikan siswa yang keluar kontrol menyebutkan jawaban ketika melakukan evaluasi berupa tes.

Penelitian mengenai penguatan pernah dilakukan oleh Riskayuni (2012). Penelitian yang dilakukan Riskayuni (2012) membahas mengenai penggunaan penguatan verbal dalam pembelajaran berbicara. Dalam penelitiannya, Riskayuni (2012) menyimpulkan bahwa guru telah melakukan penguatan verbal dalam pembelajaran berbicara dan hal tersebut berkontribusi positif terhadap aktivitas dan hasil belajar siswa.

Selain itu, penelitian mengenai penguatan juga pernah dilakukan oleh Wijayanto (2013). Penelitian oleh Wijayanto (2013) yang merupakan penelitian tindak kelas menunjukkan bahwa peningkatan motivasi dengan keterampilan penguatan terbukti efektif meningkatkan motivasi belajar siswa kelas V SD Negeri 1 Gandon Kecamatan Kaloran, Kabupaten Temanggung.

Penelitian mengenai penguatan juga dilakukan oleh Putra, dkk (2014) yang membahas mengenai penerapan penguatan negatif bagi anak tunalaras kelas 2 di SLB Hikmah Miftahul Jannah Padang. Dalam penelitiannya, Putra, dkk (2014) menyimpulkan bahwa penggunaan kata-kata kasar bagi anak tunalaras kelas II di SLB Hikmah Miftahull Jannah Padang dapat di turunkan melalui pemberian reinforcement negatif berupa teguran. Penelitian yang dilakukan Putra, dkk (2014) merupakan penelitian eksperimen.

Oleh sebab itu, dilakukan penelitian lebih lanjut untuk mendapatkan hasil yang lebih detail terkait penguatan dalam pembelajaran bahasa Jepang oleh guru bahasa Jepang di SMA Negeri 1 Sukasada. Hal yang menjadi pembeda antara penelitian ini dengan penelitian lainnya yang telah dipaparkan sebelumnya adalah penelitian ini menggunakan rancangan penelitian deskriptif kualitatif dengan variabel penelitian berupa penguatan verbal maupun nonverbal, dengan guru sebagai subjek penelitian, serta bertujuan untuk mengetahui modelmodel penguatan yang digunakan oleh guru bahasa Jepang dan bagaimana penggunaan bahasa Jepang dan kejepangan dalam penguatan oleh guru bahasa Jepang di SMA Negeri 1 Sukasada.

\section{Metode}

Penelitian ini menggunakan rancangan penelitian deskriptif kualitatif. Menurut Bungin (2009:68) penelitian deskriptif kualitatif merupakan penelitian yang bertujuan untuk menggambarkan, meringkaskan berbagai kondisi, berbagai situasi, atau berbagai fenomena realitas sosial yang ada di masyarakat yang menjadi objek penelitian, dan berupaya menarik realitas itu ke permukaan sebagai suatu ciri, karakter, sifat, model, tanda, atau gambaran tentang kondisi, situasi, ataupun fenomena tertentu. Dengan demikian, dapat dikatakan bahwa penelitian deskriptif kualitatif menekankan pada penelitian yang menggambarkan dan menginterpretasikan berbagai kondisi, berbagai situasi, ataupun fenomena yang digunakan sebagai objek penelitian oleh peneliti.

Alasan digunakannya rancangan penelitian deskriptif kualitatif adalah karena data-data yang didapatkan untuk menjawab rumusan masalah dari penelitian ini merupakan data yang berupa kata-kata, gambar dan perilaku yang akan dianalisis dengan memberi pemaparan 
gambaran mengenai situasi yang diteliti dalam bentuk uraian kata-kata, bukan dalam bentuk bilangan atau angka statistik.

Subjek penelitian dalam penelitian ini adalah guru bahasa Jepang di SMA Negeri 1 Sukasada. Di SMA Negeri 1 Sukasada terdapat seorang guru bahasa Jepang yang mengelola lima kelas $X$, satu kelas XI IPB, dan satu kelas XII IPB, dengan siswa yang memiliki berbagai karakter yang mencerminkan perilaku yang bersifat mendukung ataupun kurang mendukung pembelajaran, sehingga data yang diperoleh diharapkan akan lebih bervariasi. Guru tersebut juga sudah lulus sertifikasi dan memiliki pengalaman mengajar yang cukup lama. Sebagai guru yang telah lulus sertifikasi tentunya sudah menguasai keterampilan dasar mengajar dan memiliki keahlian dalam mengajar.

Pengumpulan data dilakukan dengan tiga metode yaitu metode observasi, dokumentasi dan wawancara. Observasi dilakukan untuk mendapatkan data mengenai bentuk-bentuk penguatan dan penggunaan bahasa Jepang dan kejepangan dalam penguatan yang digunakan oleh guru bahasa Jepang dalam pembelajaran bahasa Jepang di SMA Negeri 1 Sukasada. Dokumentasi dilakukan dengan hasil berupa foto yang digunakan sebagai bukti dan agar lebih memperjelas kegiatan memberikan penguatan yang dilakukan guru dalam pembelajaran, terutama penguatan dalam bentuk nonverbal. Sedangkan metode wawancara, yaitu wawancara tidak terstruktur digunakan untuk mengklarifikasi dan melengkapi data hasil observasi.

Setelah data diperoleh, kemudian dilakukan analisis data. Analisis data dalam penelitian kualitatif, dilakukan pada saat pengumpulan data berlangsung, dan setelah selesai pengumpulan data dalam periode tertentu. Menurut Miles dan Huberman (dalam Sugiyono, 2009:246), aktivitas dalam analisis data kualitatif yaitu data reduction, data display, dan conclusion drawing/verification.

Pada penelitian ini, uji kredibilitas dilakukan hanya sebatas menggunakan triangulasi teknik. Triangulasi teknik dilakukan dengan cara mengecek data dari sumber yang sama namun dengan cara yang berbeda. Dalam hal ini, derajat kepercayaan dilakukan dengan cara mengecek data hasil observasi dengan data hasil wawancara dari sumber yang sama. Selain itu, derajat kepercayaan data dilakukan dengan menggunakan bahan referensi. Bahan referensi adalah adanya pendukung untuk membuktikan data yang telah ditemukan peneliti (Sugiyono, 2009:375). Dalam hal ini, bahan referensi dalam laporan penelitian dilengkapi dengan foto-foto agar dapat lebih dipercaya.

\section{Hasil dan Pembahasan}

Pembelajaran dapat dikatakan merupakan suatu upaya yang dilakukan untuk mendorong siswa belajar sehingga dapat membangun pemahaman siswa dan tujuan pembelajaran dapat tercapai. Usaha-usaha untuk mendorong siswa belajar merupakan salah satu peran penting seorang guru. Seorang guru mempunyai peran untuk selalu dapat menjaga dan meningkatkan motivasi siswa untuk belajar. Pemberian motivasi ini salah satunya adalah dengan memberikan siswa penguatan yang merupakan salah satu keterampilan dasar yang harus dikuasai sebagai guru yang profesional.

Guru bahasa Jepang di SMA Negeri 1 Sukasada sudah menggunakan penguatan dalam kegiatan pembelajaran bahasa Jepang baik dalam bentuk verbal maupun nonverbal. Penguatan-penguatan ini secara umum dilakukan guru untuk memberikan, menjaga dan meningkatkan motivasi siswa. Motivasi yang guru berikan baik yang bertujuan untuk menimbulkan, menjaga bahkan meningkatkan hal-hal positif yang dapat meningkatkan kualitas pembelajaran seperti dengan memberikan pujian, penghargaan atau persetujuan maupun bertujuan untuk menghentikan kebiasaan-kebiasaan siswa yang tidak baik seperti dalam bentuk teguran dan nasihat. Hal ini sejalan dengan pendapat Usman (2005:80) yang menyatakan bahwa penguatan (reinforcement) adalah segala bentuk respons, apakah berbentuk verbal ataupun nonverbal, yang merupakan bagian dari modifikasi tingkah laku guru terhadap tingkah laku siswa, yang bertujuan untuk memberikan informasi atau umpan balik (feedback) bagi si penerima (siswa) atas perbuatannya sebagai suatu tindakan dorongan ataupun koreksi. 
Berdasarkan hasil wawancara, guru menyebutkan bahwa pemberikan penguatan adalah supaya hasil dari pembelajaran sesuai seperti yang diharapkan, karena motivasi dapat mendukung suasana pembelajaran yang nantinya bermuara pada tujuan pembelajaran yang telah ditetapkan, sehingga faktor yang menjadi pertimbangan dalam menberikan penguatan adalah dilihat berdasarkan perilaku target (siswa) yang akan diberikan penguatan. Jika siswa menunjukkan perilaku positif akan diberikan penguatan yang positif, sedangkan jika siswa melakukan tindakan negatif akan diberikan penguatan negatif. Hal ini dapat dikatakan bahwa guru menggunakan perilaku siswa sebagai tolok ukur dalam memberikan penguatan.

Guru juga menyebutkan bahwa setiap penguatan memiliki efektivitasnya masingmasing, asalkan digunakan sesuai dengan situasi dan kondisinya. Pendapat guru tersebut mendukung penggunaan penguatan secara bervariasi. Sesuai dengan pendapat yang disampaina Barnawi dan M. Arifin (2012: 212), Djamarah (2005: 123), Hasibuan dkk (1994: 58), dan Usman (2005: 83) yang menyatakan bahwa pemberian penguatan harus bervariasi, tidak terbatas pada satu jenis saja, karena akan menimbulkan kebosanan dan lamakelamaan akan kurang efektif. Dengan kata lain seefektif apapun suatu penguatan, jika pengguanaanya tidak divariasikan akan menimbulkan kebosanan bagi siswa dan lamakelamaan kurang efektif.

Dalam memberikan penguatan, guru bahasa Jepang SMA Negeri 1 Sukasada dalam pembelajaran bahasa Jepang menggunakan berbagai variasi penguatan, yaitu penguatan verbal baik dalam bentuk kata maupun kalimat dan penguatan nonverbal dalam bentuk penguatan berupa mimik dan gerak badan (gestural), penguatan dengan cara mendekati, penguatan dengan sentuhan, dan penguatan dengan kegiatan yang menyenangkan. Guru bahkan melakukan kombinasi penguatan, yaitu berupa kombinasi penguatan verbal dengan gestural, verbal dengan mendekati, verbal dengan sentuhan, mendekati dengan gestural, serta verbal dengan mendekati dan gestural.

Berdasarkan hasil pengamatan dan wawancara yang telah dilakukan, maka dapat dipaparkan bahwa penguatan verbal yang guru gunakan berupa kata dan kalimat baik dalam bentuk pujian, penghargaan, pengakuan atau persetujuan maupun dukungan yang bertujuan untuk mengapresiasi usaha, keberhasilan, inisiatif dan keaktifan, keberanian serta pemahaman siswa. Selain itu, penguatan verbal dilakukan dalam bentuk nasihat dan teguran untuk menghilangkan perilaku buruk siswa seperti kebiasaan ribut siswa, ketidakfokusan siswa terhadap pembelajaran, tindakan-tindakan siswa yang tidak mengikuti intruksi guru, kekurangdisiplinan siswa, dan kekeliruan yang berkali-kali dilakukan siswa. Pemberian teguran yang dilakukan guru senada dengan pendapat yang disampaikan Djamarah dan Aswan Zain (2006:190) yang menyatakan bahwa salah satu cara untuk menghentikan gangguan anak didik adalah dengan memberikan teguran.

Penguatan berupa mimik dan gerak badan (gestural) yang digunakan guru memiliki fungsi yang tidak jauh berbeda dengan penguatan verbal, yaitu untuk memberikan pujian, penghargaan, pengakuan atau peretujuan maupun dukungan dan untuk menyikapi perilaku buruk siswa seperti membuat keributan dan tidak fokus pada kegiatan pembelajaran. Penguatan gestural yang dilakukan guru berupa pengekspresian mimik wajah, seperti senyuman dan mengangkat alis untuk memberikan kesan ramah, antusias, kehangatan, senang dan kagum terhadap usaha dan tingkah laku siswa. Senyuman juga digunakan guru untuk memperhalus teguran yang diberikan guru. Penguatan gestural berupa anggukan kepala dilakukan guru sebagai bentuk persetujuan atau pengakuan guru terhadap tindakan siswa, penguatan gestural dengan diam sejenak sebagai tanda tidak memihak siswa dan isyarat meletakkan jari telunjuk di depan bibir digunakan ketika siswa ribut. Penguatan gestural lainnya sering dilakukan guru dengan mengkombinasikannya dengan penguatan verbal yaitu penguatan gestural berupa tepukan tangan sebagai bentuk penghargaan terhadap usaha dan keaktifan siswa. Penguatan gestural berupa menunjuk siswa sebagai bentuk dukungan atau pengakuan guru terhadap pernyataan yang disampaikan siswa, mempertegas penguatan verbal dan sebagai pengahargaan yang dapat menjadikan siswa yang diberikan penguatan sebagai pusat perhatian untuk beberapa saat. Penguatan gestural berupa acungan jempol sebagai bentuk pujian terhadap usaha siswa. Penguatan gestural 
berupa ojigi (membungkukkan badan) sebagai bentuk penghargaan atas keaktifan, bantuan dan aprsiasi siswa selama proses pembelajaran. Penguatan gestural berupa isyarat membentuk huruf $\mathrm{T}$ menyerupai isyarat charged time out dalam olahraga basket untuk menghentikan keributan siswa serta untuk meminta perhatian siswa, dan penguatan gestural berupa isyarat stop yang guru berikan ketika siswa protes saat penilaian dihentikan dan menimbulkan keributan sehingga memberi kesan kurang disiplin. Penggunaan penguatan gestural yang dikombinasikan dengan penguatan verbal sesuai dengan pendapat Djamarah (2005: 120) yang menyatakan bahwa pemberian penguatan gestural sangat erat sekali dengan pemberian penguatan verbal.

Berdasarkan hasil wawancara, guru menyebutkan bahwa guru mengkombinasikan penguatan mimik wajah dan gerak badan (gestural) dengan penguatan verbal menggunakan kosakata bahasa Jepang yang mukin tidak dipahami oleh siswa karena merupakan kosakata baru yang mungkin baru didengarnya. Dengan demikian, dapat dikatakan pula penguatan gestural dapat berfungsi untuk mebantu siswa dalam memahami kosakata baru dalam bahasa Jepang yang digunakan guru sebagai penguatan.

Penguatan mendekati dilakukan guru sebagai bentuk dukungan guru terhadap aktivitas siswa ketika siswa membaca atau mempelajari catatannya kembali, ketika siswa mengerjakan tugas, berlatih pola kalimat dan percakapan, saat siswa mencatat, serta saat siswa bertanya. Penguatan mendekati dilakukan pada aktivitas siswa tersebut bertujuan untuk memberikan bimbingan dan mengontrol aktivitas siswa sebagai bentuk perhatian dan kepedulian guru terhadap siswa. Pemberian penguatan mendekati sesuai dengan pendapat yang disampaikan Barnawi dan M. Arifin (2012:210) bahwa penguatan mendekati dapat memberi kesan perhatian dan dukungan terhadap aktivitas siswa.

Guru mengatakan penggunaan penguatan mendekati dilakukan ketika memberi pertanyaan pada satu orang siswa. Misalnya ketika jawaban yang diberikan siswa kurang jelas, ketika didekati siswa biasanya mengerti bahwa jawabannya perlu diperjelas ataupun diperbaiki. Ketika jawaban yang diberikan sudah diperjelas oleh siswa, maka guru akan kembali ke tempat semula yang menunjukkan bahwa guru milik siswa secara keseluruhan atau fokus guru kembali kepada seluruh siswa di dalam kelas. Dengan demikian dapat dikatakan bahwa penguatan mendekati dapat dilakukan guru untuk memperjelas bagaimana pembagian fokus perhatian kepada siswa dilakuakan. Ketika penguatan medekati dilakukan, maka akan menunjukkan apakah fokus perhatian guru ditujukan kepada siswa tertentu, kelompok tertentu ataupun kepada seluruh siswa. Selain itu, perlakuan guru untuk memperjelas jawaban yang diberikan siswa merupakan bentuk dorongan dari guru agar siswa dapat memberi jawaban yang jelas dan tepat, tidak langsung menyalahkan. Berdasarkan pengamatan saat guru melakukan penguatan mendekati, ketika siswa memberikan jawaban yang kurang tepat, guru juga akan membantu dan membimbing siswa agar dapat memberikan jawaban yang sesuai harapan.

Penguatan sentuhan erat kaitannya dengan penguatan mendekati. Penguatan sentuhan yang dilakukan guru sudah dilakukan dengan sewajarnya, yaitu dengan menyentuh bahu dan punggung siswa, penguatan dilakukan untuk menangani siswa secara personal. Tidak jauh berbeda dengan penguatan mendekati, penguatan sentuhan dilakukan ketika membimbing siswa yang sedang mengerjakan tugas untuk membangun suasana yang akrab dan positif dengan siswa serta sebagai bentuk dukungan terhadap aktivitas yang dilakukan siswa dan sebagai perhatian guru terhadap siswa.

Penguatan sentuhan kadang guru kombinasikan dengan penguatan verbal. Dalam hal ini penguatan sentuhan dapat mepertegas makna dari penguatan verbal sebagai betuk pujian dan persetujuan guru terhadap pekerjaan siswa, menunjukkan bahwa guru senang terhadap pekerjaan siswa, dan dapat digunakan sebagai bentuk dorongan atau motivasi untuk membesarkan hati siswa yang memiliki kekurangan sehingga siswa bersangkutan tidak berkecil hati.

Penguatan dengan kegiatan yang menyenangkan dilakukan guru ketika siswa melakukan pencapaian yang lebih dibandingkan siswa yang lainnya, yaitu dengan cara menjadikan pasangan siswa sebagai model untuk menampilkan kembali demonstrasinya. Penguatan ini dilakukan sebagai bentuk pengakuan dan penghargaan terhadap usaha yang 
dilakukan siswa, sehingga dapat menjadi kebanggaan tersendiri bagi siswa bersangkutan dan dapat menjadi contoh bagi yang lain. Pemberian penguatan ini sudah sesuai dengan pendapat yang disampaikan oleh Djamarah (2005: 121) yang menyatakan bahwa dalam memilih kegiatan atau tugas hendaknya dipilih yang memiliki relevansi dengan tujuan pelajaran yang dibutuhkan dan digunakan siswa. Penguatan dengan kegiatan yang menyenangkan yang dilakukan guru tidak hanya bermanfaat bagi yang diberikan penguatan, bahkan bermanfaat bagi siswa lainnya.

Dari pengamatan yang telah dilakukan, penguatan verbal dilakukan guru sebanyak 138 kali, penguatan mimik dan gerak badan (gestural) dilakukan sebanyak 139 kali, penguatan mendekati dilakukan sebanyak 125 kali, penguatan sentuhan diakukan sebanyak 6 kali, dan penguatan dengan kegiatan yang menyenangkan dilakukan guru sebanyak 2 kali. Dari hal tersebut, menunjukkan bahwa penguatan verbal serta penguatan mimik dan gerak badan (gestural) merupakan penguatan yang dominan dilakukan guru. Hal ini terjadi karena seperti yang telah disampaikan guru dalam wawancara bahwa penguatan verbal dan gestural memiliki fungsi yang hampir sama, yaitu dapat digunakan untuk meresponss perilaku positif dan perilaku negatif siswa. Pemberian respons berupa penguatan verbal dan gestural terhadap perilaku siswa memiliki sifat yang sederhana dan mudah dilakukan (dapat dilakukan secara spontan), serta lebih jelas atau lebih mudah dipahami siswa sebagai feedback (umpan balik) dalam interaksi pembelajaran di kelas sehingga secara langsung siswa mampu mengetahui mana hal yang baik dan tidak baik untuk dilakukan.

Meski demikian, bukan berarti penguatan yang lainnya tidak efektif, karena masingmasing penguatan dapat digunakan pada situasi dan kondisi tertentu yang terkadang akan lebih efektif jika diterapkan dibandingkan penguatan lainnya. Seperti contoh, ketika siswa mengerjakan tugas di kelas, guru dapat menggunakan penguatan mendekati karena dapat memberi kesan perhatian dan dapat mengarahkan serta membimbing siswa dalam mengerjakan tugas. Ketika memberi ucapan selamat atas suatu pencapaian yang dilakukan siswa, akan lebih berkesan bagi siswa jika guru memberikan penguatan sentuhan berupa jabatan tangan.

Guru juga dapat memberikan penguatan dengan kegiatan yang menyenangkan ketika siswa melakukan suatu pencapaian sehingga dapat lebih bermakna bagi siswa. Ketika mengembalikan tugas siswa yang telah diperiksa, akan lebih bermakna dan efektif jika guru memberikan penguatan berupa simbol dalam bentuk nilai dan komentar terhadap hasil pekerjaan siswa. Ketika siswa mampu memenangkan suatu kompetisi yang dilaksanakan guru dalam pembelajaran, guru dapat memberikan penguatan berupa benda sebagai hadiah sehingga akan lebih berkesan dan bermakna bagi siswa, namun penerapannya perlu untuk dibatasi, agar siswa tidak terlalu bergantung terhadap hadiah. Selain itu, adanya teori mengenai cara menggunakan penguatan yang perlu diterapkan secara bervariasi agar siswa tidak merasa bosan sehingga penguatan menjadi lebih efektif juga merupakan hal yang perlu menjadi pertimbangan agar guru tidak hanya bergantung terhadap penggunaan penguatan tertentu saja.

Hasil pengamatan menunjukkan bahwa guru tidak melakukan penguatan simbol atau benda. Berdasarkan hasil wawancara, guru menyebutkan bahwa penguatan simbol diberikan guru dengan cara memberikan komentar dan nilai pada tugas-tugas tertulis atau PR siswa yang tentunya guru membutuhkan waktu untuk memeriksanya terlebih dahulu sebelum menunjukkan hasilnya kepada siswa. Selain itu, ketika guru melakukan penilaian di dalam kelas seperti halnya ketika melakukan penilaian terhadap demonstrasi siswa, hasil nilai siswa tidak langsung ditunjukkan kepada siswa saat itu juga, tetapi dilakukan setelah sekitar 3-4 kali pengambilan nilai, nilai kemudian baru dicetak dan ditunjukkan kepada siswa. Hal tersebut dilakukan agar guru maupun siswa dapat melihat perkembangan studi siswa dan dapat digunakan sebagai bahan evaluasi atau cerminan bagi guru maupun siswa sendiri, selain itu dirasa lebih efesien karena ketika terdapat nilai siswa yang belum memenuhi standar, guru dapat meminta siswa untuk melakukan remidial dengan mempertimbangkan dan menentukan jadwal remidial terlebih dahulu. Sedangkan pemberian bonus atau nilai tambahan tidak diberikan guru untuk mencegah ketidakadilan. Penilaian 
mengenai keaktifan siswa, ketekunan siswa, dan lain sebagainya dilakukan lebih kearah penilaian secara afektif.

Penguatan dalam bentuk benda tidak dilakukan guru karena penguatan benda hanya diberikan guru saat adanya hal-hal yang bersifat kompetisi. Penguatan diberikan dengan cara membagi siswa kedalam kelompok-kelompok untuk berkompetisi. Hadiah yang diberikan kepada pemenang sifatnya tidak perindividu, tetapi secara kelompok. Misalnya kelompok terdiri dari 5 orang, maka hadiah yang diberikan sebanyak 4 buah agar dapat menumbuhkan rasa kebersamaan, empati, berbagi, menumbuhkan sikap musyawarah dan diskusi. Guru juga menyebutkan bahwa berdasarkan pengalaman guru mengajar, guru sering mengalami kendala alokasi waktu yang menyebabkan guru harus berusaha melakukan pembelajaran secara efisien, termasuk menghilangkan kegiatan pembelajaran yang bersifat kompetisi. Selain itu juga, menurut Hasibuan dkk (1994: 61), penguatan berupa simbol atau benda, terutama yang berupa benda agar tidak terlalu sering digunakan, siswa tidak terbiasa untuk mengharapkan memperoleh benda tertentu sebagai imbalan terhadap penampilannya.

Secara umum, guru sudah menggunakan penguatan dengan baik. Guru sudah mengikuti cara-cara dalam memberikan penguatan. Guru sudah menggunakan penguatan sesuai dengan targetnya, baik penguatan kepada individu tertentu ataupun kelompok. Untuk memberikan penguatan pada salah satu peserta didik, guru melakukannya dengan cara menyebutkan nama target, memandang ke arah target, menunjuk target, dan mendekati target sehingga penguatan menjadi tepat sasaran. Penguatan juga telah diberikan guru segera setelah siswa memunculkan tindakan, dan guru sudah melakukan variasi dan bahkan kombinasi penguatan untuk memberikan penekanan dan meningkatkan makna penguatan.

Tetapi, guru tidak menerapkan penguatan tidak penuh, karena dalam memberikan pertanyaan, guru biasanya akan menampung semua jawaban siswa kemudian menyimpulkannya bersama-sama. Dengan demikian guru telah berusaha untuk melatih siswa untuk berfikir dan berani mengemukakan pendapat. Selain itu, ketika siswa memberikan jawaban yang tidak sesuai harapan, guru akan melontarkan pertanyaan kepada siswa lain. Hal ini sesuai dengan pendapat Usman (2005: 82) dan Hasibuan dkk (1994: 59) yang menyampaikan bahwa apabila siswa tidak dapat memberikan jawaban sesuai dengan yang diharapkan, guru jangan langsung menyalahkan, tetapi memindahkan giliran untuk menjawab pertanyaan tersebut kepada siswa yang lain. Dengan demikian, jika pertanyaan tersebut terjawab oleh siswa lain, maka siswa tadi tidak terlalu tersinggung harga dirinya, dan ia dapat menyadari kesalahannya, serta dapat membantu dirinya untuk tetap berusaha belajar.

Guru juga sudah berusaha untuk menggunakan penguatan sesuai dengan prinsipprinsip dalam pemberian penguatan. Seperti yang sudah dijelaskan sebelunmnya, penguatan yang guru berikan sudah memperhatikan prinsip kehangatan dan antusiasme yang ditunjukkan melalui senyuman, suara dan gerak mimik dalam memberikan penguatan. Sehingga penguatan yang guru berikan menimbulkan kesan bersungguh-sungguh. Guru juga sudah mengamalkan prinsip kebermaknaan dalam memberikan penguatan. Pengutan yang diberikan guru diberikan sesuai dengan konteksnya dan tidak berlebihan. Penguatan juga diberikan dengan berusaha menghindari respons yang negatif. Seperti yang telah dijelaskan sebelumnya, bahwa ketika siswa tidak dapat memberikan jawaban sesuai dengan yang diharapkan, guru tidak langsung menyalahkan siswa, tetapi melempar pertanyaan kepada siswa lain.

Sedangkan dalam memberikan penguatan terutama yang bersifat teguran, secara umum diberikan guru secara tidak langsung dalam bentuk pertanyaan, memberikan penjelasan dan menyisipkan kata "mohon" sehingga dapat memperhalus teguran, serta teguran terkadang dilakukan guru dengan tidak langsung menghakimi dan tunjuk hidung langsung, melainkan disampaikan kepada seluruh atau kelompok siswa, sehingga target yang diberikan penguatan tidak merasa malu terhadap teman-temannya dan dapat memperbaiki kesalahannya, sedangkan bagi siswa yang lain teguran tersebut dapat bermanfaat sebagai pengingat agar tindakan yang kurang baik tidak dilakukan. Teguran juga dilakukan guru dikombinasikan dengan penguatan berupa senyuman untuk dapat 
memperhalus teguran yang guru berikan, tidak menunjukkan ekspresi marah, dan disampaikan dengan nada suara yang tidak terkesan membentak sehingga siswa tidak merasa takut dan menarik diri dari kegiatan pembelajaran.

Beberapa teguran diberikan guru dengan tegas, seperti teguran "Makanya tadi saya jelaskan jangan ngobrol!", teguran "Makanya dengarkan ya!" yang diawali dengan pemberian pertanyaan kepada kelompok siswa yang diberikan penguatan, dan teguran yang dikombinasikan dengan tanda stop ketika siswa menyela penjelasan guru dan protes ketika pengambilan nilai dihentikan sehingga menunjukkan kesan kekurangdisiplinan siswa. Namun penguatan yang diberikan guru tersebut tidak menyalahi pernyataan yang disampaikan oleh Djamarah dan Aswan Zain (2006:156) yang menyatakan bahwa teguran yang efektif dan dibenarkan dalam pendidikan adalah teguran yang tegas dan jelas kepada anak didik yang mengganggu serta kepada tingkah lakunya yang menyimpang, menghindari peringatan yang kasar dan menyakiti atau menggandung penghinaan, serta menghindari ocehan atau ejekan lebih-lebih yang berkepanjangan.

Namun, teguran yang diberikan guru ketika siswa menyela penjelasan guru dengan memberikan teguran "Dengarkan dulu! Belum beres, ya. Banyak yang bertanya, apa namanya, hal-hal yang akan saya sampaikan belum apa-apa sudah ditanyakan ya, tapi ternyata penguasaan materinya tidak seberapa. Tunggu dulu apa yang akan bapak/ibu guru sampaikan, ya. Kalau ada pertanyaan adakah kiranya yang kurang jelas? Baru ditanyakan ya." Teguran tersebut dapat beresiko menyinggung perasaan siswa terutama pada kalimat "tapi ternyata penguasaan materinya tidak seberapa" meskipun guru tidak bermaksud mengatakan bahwa siswa bersangkutan penguasaan materinya tidak seberapa, namun kata-kata tersebut dapat dikatakan sebagai kata-kata yang sensitif yang sifatnya terkesan meremehkan siswa dan berpotensi menyinggung perasaan. Hal seperti ini menurut peneliti ada baiknya untuk dihindari penggunaannya.

Dalam hal penggunaan bahasa Jepang dan kejepangan dalam penguatan, hasil observasi dan wawancara menunjukkan bahwa penggunaan bahasa Jepang dan kejepangan yang dilakukan guru dalam pengutan lebih banyak digunakan dalam bentuk pengutan verbal, karena menurut guru belajar bahasa harus dilakukan dengan terus mengekspos atau menggunakan bahasa itu sendiri. Guru berprinsip bahwa untuk belajar bahasa atau untuk menguasai suatu bahasa caranya adalah dengan menggunakan bahasa itu sendiri. Guru sering menggunakan pujian, persetujuan atau pengakuan dan dukungan dalam bentuk ungkapan berupa kata "Hai!", "li desu", "Sugoi desu", "Yoku dekita", "Daijoubu desu", "Arigatou gozaimashita", dan "Otsukaresamadeshita" sebagai respons terhadap jawaban siswa, usaha siswa, dan hasil kerja siswa, inisiatif siswa serta keaktifan siswa di kelas.

Kosakata yang digunakan diusahakan dengan cara mencari kosakata baru sehingga dapat memperluas wawasan siswa, setidaknya dapat menambah kosakata siswa. Meskipun yang diberikan adalah kosakata baru, guru berkeyakinan bahwa secara alami siswa akan memahami penguatan yang diberikan oleh guru, karena penggunaan penguatan diberikan secara berulang-ulang, selain itu siswa akan mengerti dengan penguatan yang diberikan guru dengan melihat konteks ketika diberikan penguatan, serta melalui gerak isyarat tertentu yang diberikan guru. Gerak isyarat yang digunakan guru adalah dalam bentuk penguatan mimik wajah dan gerak badan (gestural), seperti senyuam, anggukan kepala, acungan jempol atau tepuk tangan.

Pendapat guru yang menyatakan bahwa siswa dapat memahami secara alami dari penguatan yang guru berikan nampaknya didukung oleh pendapat yang ddisampaikan oleh para pendukung Natural method. Para pendukung Natural method percaya bahwa pembelajaran bahasa asing bisa diajarkan tanpa terjemahan atau tanpa menggunakan bahasa ibu dan makna bisa dijelaskan dengan demonstrasi, dengan contoh atau ilustrasi, atau bisa juga dengan gerakan-gerakan tubuh atau pantomim. Metode ini diperkuat oleh pandangan yang menyatakan bahwa cara terbaik mengajarkan bahasa adalah dengan menggunakannya di kelas (Padmadewi, 2015: 28).

Selain itu, pemberian penguatan "Arigatou gozaimashita" ketika mengapresiasi keaktifan dan inisiatif siswa dalam pembelajaran serta penguatan "Otsukaresamadeshita" 
ketika mengakhiri kegiatan pembelajaran sering guru gunakan disertai dengan ojigi (membungkukkan badan). Ojigi merupakan budaya Jepang sebagai bentuk penghormatan terhadap lawan bicara. Menurut Mardolina (2015: 3), ojigi adalah konsepsi dari bentuk penghormatan orang Jepang dengan cara membungkukkan badan, ini adalah implikasi bahwa orang Jepang merasa hormat dan sungkan kepada orang yang ditemuinya. Pengakuan akan eksistensi setiap individu menjadi cermin bahwa pribadinya pun akan selalu diakui orang lain. Dengan demikian dapat dikatakan bahwa ojigi yang dilakukan guru merupakan salah satu penguatan sebagai bentuk memberikan hormat, pengakuan dan penghargaan terhadap usaha siswa serta menunjukkan sikap bahwa guru tidak meremehkan setiap usaha yang dilakukan siswa.

Penguatan terkait dengan penggunaan bahasa Jepang dan kejepangan juga dilakukan guru dengan cara pemberian nasihat yang diberikan guru dengan cara menceritakan kebiasaan orang Jepang terkait kejujuran orang Jepang ketika mereka menemukan barang milik orang lain disuatu tempat. Penguatan ini diberikan dengan tujuan memberikan pembelajaran moral kepada siswa agar dapat mengikuti kebiasaan positif yang dilakukan oleh orang Jepang. Ketika kegiatan demonstrasi dilakukan, terlihat seorang siswa yang meminjam penggaris milik temannya dengan cara yang kurang sopan untuk keperluan demonstrasi di depan kelas. Penguatan ini guru berikan sekaligus digunakan sebagai pengantar materi yang akan dibahas pada pertemuan saat itu, yaitu mengenai kepemilikan benda dalam bahasa Jepang. Dengan diberikan penguatan tersebut dapat digunakan sebagai bahan renungan bagi siswa agar menghilangkan perilaku-perilaku negatif seperti mengakui atau mengantongi benda milik orang lain yang ditemukannya dan agar dapat bertindak dengan semestinya ketika ingin meminjam benda milik orang lain.

Dalam pemberian tugas, guru juga mengatakan terkadang memberikan perbandingan bahwa di Jepang meski siswa dalam keadaan libur, namun tetap diberikan tugas oleh guru. Hal ini dilakukan guru dengan harapan agar siswa dapat termotivasi untuk meniru kebiasaan baik orang Jepang dan untuk berusaha mengubah pola pikir siswa yang masih menganggap bahwa pemberian tugas saat libur merupakan beban. Selain itu, berdasarkan hasil wawancara, untuk memotivasi siswa agar terus belajar, guru memberikan penguatan dengan menceritakan kebiasaan atau budaya orang Jepang yang memanfaatkan waktu senggang untuk membaca tanpa memandang tempat dan waktu, serta guru juga memberikan penguatan tentang bagaimana prinsip orang Jepang yang berusaha sendiri sebisa mungkin sebelum meminta bantuan kepada orang lain. Penguatan-penguatan dalam bentuk perbandingan budaya, pola pikir dan prinsip orang Jepang dilakukan guru dengan harapan siswa dapat termotivasi untuk melakukan hal-hal positif dengan meniru budaya, pola pikir dan prinsip orang Jepang.

Guru bahasa Jepang di SMA Negeri 1 Sukasada mengungkapkan bahwa dengan menyisipkan bahasa Jepang dan kejepangan ke dalam penguatan, selain untuk menjaga dan meningkatkan motivasi siswa, juga dapat menambah wawasan dan penguasaan kosakata bahasa Jepang siswa. Selain itu, manfaat yang didapatkan siswa adalah adanya ketertarikan tertentu pada siswa ketika mengetahui hal-hal baru berkaitan dengan bahasa Jepang, misalnya kata sugoi yang diucapkan dengan gaya bahasa remaja Jepang seperti suge, mereka sering menirukannya dan mengulang-ngulangnya dalam kegiatan sehari-hari ketika siswa merasa bahwa temannya telah melakukan suatu pencapaian tertentu. Dengan demikian, ketertarikan siswa akan hal-hal baru terkait bahasa Jepang dapat meningkatkan minat dan motivasi siswa untuk belajar bahasa Jepang dan siswa secara tidak sadar telah membiasakan diri untuk menggunakan bahasa Jepang ketika dalam kegiatan sehari-hari mereka dengan menirukan penggunaan penguatan yang dilakukan guru.

\section{Simpulan dan Saran}

Berdasarkan hasil dan pembahasan penelitian yang telah dipaparkan, maka dapat diambil kesimpulan sebagai berikut.

Guru bahasa Jepang dalam pembelajaran bahasa Jepang di SMA Negeri 1 Sukasada melakukan penguatan berupa penguatan verbal dan penguatan nonverbal, baik penguatan 
mimik wajah dan gerak badan (gestural), penguaatan dengan cara mendekati, penguatan dengan sentuhan, dan penguatan dengan kegiatan yang menyenangkan. Untuk penguatan berupa simbol atau benda (token) tidak tampak dilakukan guru dalam pengamatan yang telah dilakukan, karena penguatan berupa simbol tidak dapat guru berikan langsung ketika itu juga di dalam kelas atas pertimbangan efesiensi dan terbatasnya alokasi waktu. Sedangkan penguatan dalam bentuk benda tidak guru lakukan karena penguatan tersebut digunakan guru sebagai hadiah untuk hal-hal yang bersifat kompetisi dan karena terbatasnya alokasi waktu.

Penggunaan bahasa Jepang dan kejepangan dalam penguatan dilakukan guru dengan cara menggunakan penguatan verbal dalam bentuk pujian, dukungan, pengakuan, dan penghargaan dalam bahasa Jepang berupa ungkapan "Hai!", "li desu", "Sugoi desu", "Yoku dekita", "Daijoubu desu", "Arigatou gozaimashita", dan "Otsukaresamadeshita", penguatan verbal dengan menceritakan perbandingan budaya, pola pikir, dan prinsip orang Jepang mengenai kejujuran, kerja keras dan dalam hal memanfaatkan waktu, serta pengamalan budaya jepang dengan cara menggunakan penguatan gestural berupa ojigi.

Berdasarkan penelitian yang telah dilakukan, maka saran yang dapat disampaikan adalah sebagai berikut.

Penguatan memang terlihat sederhana, tetapi guru hendaknya perlu untuk mempelajari mengenai pemberian penguatan, karena penguatan sangat penting dalam proses pembelajaran dan dalam penggunaannya memerlukan keterampilan agar penguatan yang guru berikan bersifat efektif dan tidak terkesan dibuat-buat.

Penguatan dalam bentuk benda terkadang perlu untuk diberikan agar dapat memberikan semangat dan motivasi belajar kepada siswa. Penguatan dapat diberikan tidak harus dalam bentuk kegiatan yang bersifat kompetisi yang sifatnya mengambil alokasi waktu kegiatan pembelajaran di sekolah, tetapi dapat diberikan seperti dengan cara memberikan tugas atau pekerjaan rumah yang disesuaikan sedemikian rupa kepada siswa, dan tugas dengan hasil terbaik dapat diberikan hadiah.

\section{Daftar Pustaka}

Barnawi dan M. Arifin. 2012. Etika da Profesi Kependidikan. Cetakan pertama. Yogyakarta: Ar-Ruzz Media.

Bungin, Burhan. 2009. Penelitian Kualitatif Komunikasi, Ekonomi, Kebijakan Publik, dan IImu Sosial lainnya. Cetakan ketiga. Jakarta: Kencana Prenada Media Group.

Djamarah, S. B. 2005. Guru dan Anak Didik dalam Interaksi Edukatif Suatu Pendekatan Teoritis Psikologis. Cetakan ketiga. Jakarta: PT Rineka Cipta.

Djamarah, S. B. dan Aswan Zain. 2006. Strategi Belajar-mengajar. Cetakan ketiga. Jakarta: PT Adi Mahasatya.

Hasibuan dkk. 1994. Proses Belajar Mengajar Keterampilan Dasar Pengajaran Mikro. Cetakan ketiga. Bandung: PT Remaja Rosdakarya.

Mardolina, Yiska. 2015. "Pengakuan akan eksistensi setiap individu menjadi cermin bahwa pribadinya pun akan selalu diakui orang lain". Skripsi. Jurusan Ilmu Komunikasi, Fakultas IImu Sosial dan IImu Politik, Universitas Hasanuddin, Makassar. Tersedia pada http://repository.unhas.ac.id/bitstream/handle/123456789/15652/YISKA\%20MARDOLI NA\%20-\%20E31111105.pdf?sequence=1 (diakses pada 30 September 2016).

Padmadewi, Ni Nyoman. 2015. Strategi Pembelajaran Bahasa. Cetakan kedua. Singaraja: Undiksha Press.

Putra, F. P., dkk. 2014. "Reinforcement merupakan Salah Satu Alternatif untuk Mengurangi Perilaku Negatif bagi Anak Tunalaras". Tersedia pada http://ejournal.unp.ac.id/index.php/jupekhu/article/viewFile/3859/3093 (diakses tanggal 27 Januari 2017). 
Riskayuni, Putu Ika. 2012. "Deskripsi Reinforcement Verbal, Aktivitas, dan Hasil Belajar Siswa dalam Pembelajaran Berbicara Kelas VII SMP Negeri 5 Singaraja”. Skripsi (tidak diterbitkan). Jurusan Pendidikan Bahasa dan Sastra Indonesia, Undiksha Singaraja.

Sugiyono. 2009. Metode Penelitian Kuantitatif Kualitatif dan R\&D. Cetakan ketujuh. Bandung: CV. Afabet.

Usman, Moh. Uzer. 2005. Menjadi Guru Profesional. Cetakan ke-17. Bandung: PT Remaja Rosdakarya.

Wijayanto, Sukma. 2013. "Keterampilan Penguatan (Reinforcement Skill) sebagai Upaya Meningkatkan Motivasi Belajar IPS pada Siswa SD Kelas V SD Negeri 1 Gandon Kecamatan Kaloran, Kabupaten Temanggung". Skripsi. Jurusan Pendidikan Pra Sekolah dan Sekolah Dasar, UNY. Tersedia pada http://eprints.uny.ac.id/16038/1/skripsi\%20sukma.pdf (diakses tanggal 22 Juni 2016). 